\title{
Pengaruh Konsentrasi dan Lama Perendaman dalam Larutan Kapur Sirih terhadap Kualitas Tepung Bonggol Pisang Kepok dan Pengaplikasian pada Cookies
}

\author{
Fawwaz Akbar Al Amin ${ }^{*}$, Noor Harini1, Sri Winarsih ${ }^{1}$, Okta Pringga Pakpahan ${ }^{1}$ \\ ${ }^{1}$ Program Studi Teknologi Pangan, Fakultas Pertanian Peternakan, Universitas Muhammadiyah \\ Malang, Malang, Indonesia \\ *Corresponding author email: fawwazalamin30@gmail.com
}

\begin{abstract}
Kepok banana tuber flour is made from banana tuber and carried out various processes, namely separation from root fibers, chopping, soaking with a solution of whiting to prevent discoloration/browning, washing, draining, drying and sifting. Cookies are foods made from low protein flour, eggs, sugar, and butter. The purpose of this study was to determine the interaction and influence of differences in concentration and duration of soaking whiting solution on the quality of kepok banana tuber flour and to determine the best quality sensory cookies formulations. This research was conducted in 2 stages. The first stage was the manufacture of kepok banana tuber flour using a factorial Randomized Block Design with 2 replications. The first factor is the concentration of whiting solution (5, 10 and $15 \%)$ and the second factor is the soaking time (30, 60 and 120 minutes). Stage 2 is making cookies using a simple randomized block design, namely the comparison of the composition of low protein wheat flour and kepok banana tuber flour with 4 levels (100\%: 0\%, 85\%: 15\%, 70\%: 30\%, and 55\%: 45\%). The results showed that in step 1 the difference in the concentration of whiting solution had a significant effect on water content, ash content, fat content and protein content. While the immersion time significantly affects the level of brightness (L), water content, ash content, fat content. The best kepok banana tuber flour is F2T1 with a brightness level $(L)$ of 71.4 , water content $6.2 \%$, ash content $6.7 \%$, fat content $4.1 \%$, protein content $3.2 \%$ and carbohydrates $79.9 \%$. In stage 2 , the best formulation for cookies was P1 (15\% banana kepok tuber flour: $85 \%$ wheat flour) with an organoleptic score of 8 (very attractive), aroma 7.3 (liked), taste 7.8 (very good) and texture 7.9 (very crunchy). Keywords: banana tuber, betel lime, brightness, browning, cookies.
\end{abstract}

\begin{abstract}
Abstrak.Tepung bonggol pisang kepok adalah tepung yang terbuat dari bonggol pisang dan dilakukan berbagai proses yaitu pemisahan dari serabut akar, perajangan, perendaman dengan larutan kapur sirih untuk mencegah perubahan warna/browning, pencucian, penirisan, pengeringan dan pengayakan. Cookies merupakan makanan yang terbuat dari tepung terigu protein rendah, telur, gula, dan mentega. Tujuan dari penelitian ini adalah mengetahui interaksi dan pengaruh dari perbedaan konsetrasi dan lama perendaman larutan kapur sirih terhadap kualitas tepung bonggol pisang kepok serta mengetahui formulasi kualitas terbaik sensoris cookies. Penelitian ini dilakukan dalam 2 tahapan. Tahapan pertama adalah pembuatan tepung bonggol pisang kepok menggunakan Rancangan Acak Kelompok (RAK) faktorial dengan 2 kali ulangan. Faktor 1 adalah konsentrasi larutan kapur sirih (5, 10 dan 15\%) dan faktor kedua adalah waktu lama perendaman (30, 60 dan 120 menit). Tahapan 2 adalah pembuatan cookies menggunakan Racangan Acak Kelompok (RAK) sederhana yaitu perbandingan komposisi tepung terigu protein rendah dan tepung bonggol pisang kepok dengan 4 level (100\%:0\%, 85\%:15\%,
\end{abstract}


70\%:30\%, dan 55\%:45\%). Hasil penelitian menunjukkan pada tahap 1 perbedaan konsentrasi larutan kapur sirih berpengaruh nyata terhadap kadar air, kadar abu, kadar lemak dan kadar protein. Sedangkan lama waktu perendaman berpengaruh nyata terhadap tingkat kecerahan (L), kadar air, kadar abu, kadar lemak. Tepung bonggol pisang kepok terbaik adalah F2T1 dengan nilai tingkat kecerahan (L) 71,4, kadar air 6,2\%, kadar abu $6,7 \%$, kadar lemak 4,1\%, kadar protein 3,2\% dan karbohidrat 79,9\%. Pada tahap 2 cookies formulasi terbaik adalah P1 (15\% tepung bonggol pisang kepok : $85 \%$ tepung terigu) dengan skor organoleptik kenampakan 8 (sangat menarik), aroma 7,3 (suka), rasa 7,8 (sangat enak) dan tekstur 7,9 (sangat renyah).

Kata kunci: bonggol pisang, browning, cookies, kapur sirih, tingkat kecerahan

\section{PENDAHULUAN}

Tanaman pisang merupakan salah satu komoditas Indonesia yang memiliki berbagai varietas. Luas perkebunan pisang tertinggi adalah provinsi Jawa Timur dengan luas 19,895 ha dan menghasilkan 1,865,772 ton. Kebun pisang terluas di Jawa Timur terdapat di kabupaten Malang dengan jumlah panen adalah 690,136 ton dari total produksi pisang di Jawa Timur. Tanaman pisang memiliki banyak manfaat terutama buah yang banyak dikonsumsi masyarakat, bagian tanaman pisang meliputi buah, daun, jantung, batang, kulit buah, dan bonggol. Bonggol pisang merupakan salah satu bagian dari tanaman pisang yang berupa umbi batang dan memiliki persentase $20 \%$ dari total bagian keseluruhan pohon pisang tersebut (Nurainy, 2013). Banyaknya tanaman pisang yang dipanen menyebabkan limbah yang terbuang semakin besar dan berakibat limbah bonggol pisang semakin banyak. Menurut Asnani (2019), bonggol pisang kepok memiliki kandungan karbohidrat sebesar 11,6 g/ $100 \mathrm{~g}$ berat basah dan 66,20 g/100 g berat kering, sehingga berpotensi menjadi alternatif bahan pangan dan bahan baku pembuatan tepung.

Proses pembuatan tepung bonggol pisang kepok memiliki beberapa permasalahan yaitu cepat mengalami proses browning. Perlu adanya proses pendahuluan agar mengurangi proses browning tersebut. Kapur sirih merupakan bahan alami yang dapat menjadi alternatif pengganti natrium bisulfit untuk menghambat proses browning. Kapur sirih sudah dikenali dan banyak digunakan oleh masyarakat secara luas. Larutan kapur sirih mempunyai ion Ca yang dapat mengurangi proses perubahan warna serta mengurangi rasa sepat yang dihasilkan pada bonggol pisang kepok. Menurut hasil penelitian Ridhayanti (2017), perendaman kapur sirih konsentrasi 15\% selama 30 menit dapat mengurangi reaksi browning sehingga warna pada keripik pepaya lebih disukai oleh panelis. Perendaman dalam larutan kapur sirih dapat berfungsi sebagai pencegah terjadinya proses browning, pengeras atau memberi tekstur, mengurangi cita rasa yang menyimpang seperti sepat dan getir.

Pemanfaatan bonggol pisang harus dilakukan agar lebih berguna. Salah satunya diolah menjadi tepung dan diaplikasikan pada pembuatan cookies. 
Cookies merupakan salah satu produk biskuit atau kue kering yang umumnya dikonsumsi sebagai cemilan. Cookies terbuat dari tepung terigu, gula, dan lemak atau margarin atau bisa juga dengan mentega dengan kadar air kurang dari 4\% dan dapat disimpan dalam waktu yang cukup lama (Jagat, 2017). Cookies disukai oleh semua kalangan usia karena memiliki rasa yang enak, manis, teksturnya renyah namun tetap lembut di mulut. Tepung yang digunakan dalam pembuatan cookies adalah tepung terigu protein rendah. Ketergantungan masyarakat Indonesia terhadap tepung terigu sangat tinggi. Berdasarkan penjelasan diatas, penelitian ini diharapkan perendaman dengan kapur sirih dapat mempertahankan kandungan dan mengurangi perubahan warna pada tepung bonggol pisang kepok. Pengolahan bonggol pisang kepok menjadi upaya untuk memanfaatkan limbah serta meningkatkan daya guna dan nilai ekonomi. Selain itu, tepung bonggol pisang yang dihasilkan dapat diaplikasikan pada olahan pangan seperti cookies.

\section{METODE PENELITIAN}

Bahan

Bahan yang digunakan meliputi bonggol pisang kepok yang diperoleh dari petani di Desa Tumpak Rejo, Kecamatan Gedangan, Kabupaten Malang, Jawa Timur (umur panen 12 bulan serta mempunyai ukuran diameter $50 \mathrm{~cm}$, kulit bonggol berwarna kecoklatan dan berat $25 \mathrm{~kg}$ ), kapur sirih diperoleh dari Pasar Landungsari-Kota Malang.

Alat

Alat yang digunakan meliputi oven (tipe WTC binder), timbangan analitik (Pioneer Ohaus PA413), waterbath (Digital Termostat), tanur (vurnace 48000), color reader (Konica Minolta CR-10).

\section{Rancangan Penelitian}

Penelitian kali ini menggunakan 2 tahap. Tahap 1 yaitu pembuatan tepung bonggol pisang kepok dengan rancangan penelitian yang digunakan adalah Rancangan Acak Kelompok (RAK) faktorial dengan 2 faktor yaitu perbedaan konsentrasi larutan kapur sirih (5\%, 10\% dan 15\%) dan lama waktu perendaman (30 menit, 60 menit dan 120 menit), sehingga diperoleh 9 kombinasi perlakuan dan tiap kombinasi diulang sebanyak 2 kali. Perlakuan terbaik pada tahap 1 akan dilanjutkan untuk penelitian tahap 2 yaitu diaplikasikan pada pembuatan cookies. Tahap 2 menggunakan Rancangan Acak Kelompok (RAK) sederhana. Perlakuan yang dicobakan adalah formulasi perbandingan tepung bonggol pisang kepok dan tepung terigu protein rendah. 


\section{Pembuatan Tepung Bonggol Pisang Kepok}

Tepung bonggol pisang kepok dibuat dengan metode Harahap (2017), dengan modifikasi. Bonggol pisang dipisahkan dari serabut akar, dikupas dan dirajang dengan ketebalan $1 \mathrm{~cm}$. Larutan kapur sirih dibuat dengan melarutkan kapur sirih konsentrasi sesuai perlakuan (5\%, 10\% dan 15\%) ke dalam $2000 \mathrm{~mL}$ air. Bonggol pisang direndam dalam larutan kapur sirih dengan perbandingan 1:1 dan lama perendaman sesuai perlakuan (30 menit, 60 menit dan 120 menit). Setelah itu dicuci hingga bersih supaya kapur hilang dan ditiriskan, kemudian dikeringkan menggunakan oven dengan suhu $70^{\circ} \mathrm{C}$ selama 20 jam untuk menurunkan kadar air. Bonggol yang sudah kering selanjutnya digiling menggunakan blender dan diayak menggunakan ayakan ukuran 80 mesh menjadi tepung bonggol pisang kepok.

\section{Pembuatan Cookies}

Pembuatan cookies didasari oleh metode Hamidah (2009), yang dimodifikasi. Bahan untuk membuat cookies yaitu $125 \mathrm{~g}$ Mentega, $140 \mathrm{~g}$ gula halus, $10 \mathrm{~g}$ baking powder dan $32 \mathrm{~g}$ kuning telur. Selanjutnya di mixer selama 2 menit, dan masukkan tepung (tepung terigu protein rendah: tepung bonggol pisang kepok) sebanyak $200 \mathrm{~g}$, kemudian dicampur dengan mixer kecepatan rendah. Adonan yang sudah jadi dicetak kemudian dioven dengan suhu $180^{\circ} \mathrm{C}$ selama 60 menit.

\section{Parameter Penelitian}

Parameter pada penelitian ini meliputi parameter kimia (kadar air (Sudarmadji, 2007), kadar abu (Sudarmadji, 2007), kadar lemak (Sudarmadji, 2007), kadar protein (Sudarmadji, 2007), total karbohidrat (AOAC, 2005)), fisika (tingkat kecerahan (Sudarmadji, 2007)) dan organoleptik (kenampakan, aroma, rasa) (SNI, 2011).

\section{Analisa Penelitian}

Pengolahan data dilakukan menggunakan metode analisa sidik ragam (ANOVA) yang dilanjutkan dengan uji pembeda menggunakan uji DMRT (Duncan Multiple Range Test). Perlakuan terbaik dilakukan dengan menggunakan metode De Garmo sehingga didapatkan hasil yang terbaik.

\section{HASIL DAN PEMBAHASAN}

\section{Tingkat Kecerahan (L)}

Berdasarkan hasil analisis ragam menunjukkan bahwa tidak terjadi interaksi antara konsentrasi kapur sirih dan lama perendaman, namun konsentrasi kapur sirih tidak berpengaruh nyata dan lama perendaman berpengaruh nyata $(\alpha=5 \%)$ terhadap tingkat kecerahan $(L)$. 


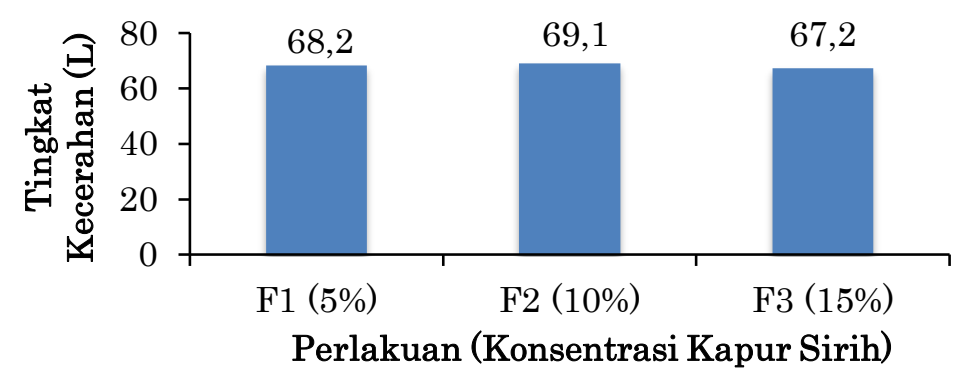

Gambar 1. Histogram Tingkat Kecerahan (L) Tepung Bonggol Pisang Kepok dengan Perlakuan Konsentrasi Kapur Sirih

Tingkat kecerahan (L) tepung bonggol pisang kepok dengan konsentrasi kapur sirih yang berbeda berkisar antara 67,2-69,1. Tingkat kecerahan (L) cenderung meningkat dan menurun seiring dengan penambahan konsentrasi kapur sirih. Menurut Ridhayanti (2017) penggunaan $\mathrm{Ca}(\mathrm{OH})_{2}$ dapat mempertahankan warna, ion Ca akan mudah melakukan proses absorpsi (peristiwa penyerapan) dalam jaringan bahan sehingga dapat mempertahankan warna yang disebabkan oleh efek ion Ca. Pencoklatan non enzimatis dapat dicegah dengan perendaman larutan kapur sirih, karena ion $\mathrm{Ca}^{+2}$ berikatan dengan asam amino dan menghambat reaksi antara amino dengan gula reduksi yang menyebabkan pencoklatan (Ridhayanti, 2017).

Tabel 1. Nilai Tingkat Kecerahan (L) Tepung Bonggol Pisang Kepok dengan Perlakuan Lama Perendaman

\begin{tabular}{rc}
\hline Perlakuan & Tingat Kecerahan (L) \\
\hline T1 (Lama perendaman 30 menit) & $70,1^{\mathrm{b}}$ \\
T2 (Lama perendaman 60 menit) & $67,4^{\mathrm{a}}$ \\
T3 (Lama perendaman 120 meni) & $67,0^{\mathrm{a}}$ \\
\hline
\end{tabular}

Keterangan: Angka rerata yang diikuti huruf yang sama menunjukkan tidak berbeda nyata berdasarkan Uji Duncan pada taraf $5 \%$.

Tingkat kecerahan (L) tepung bonggol pisang kepok dengan lama perendaman kapur sirih yang berbeda berkisar antara 67-70,1. Tingkat Kecerahan (L) tertinggi pada perlakuan lama perendaman kapur sirih 30 menit sebesar 70,1 dan berbeda nyata dengan perlakuan lama perendaman kapur sirih 60 menit sebesar 67,4 dan 120 menit sebesar 67. Menurut Carina (2012), ion Ca pada larutan kapur sirih akan mengikat asam amino dalam jaringan bahan sehingga dapat mencegah proses pencoklatan non-enzimatis hingga waktu tertentu, jika terlalu lama komponen yang terdapat di larutan kapur sirih akan ikut menempel pada bahan. 


\section{Kadar Air}

Berdasarkan hasil analisis ragam menunjukkan bahwa tidak terjadi interaksi antara konsentrasi kapur sirih dan lama perendaman, namun konsentrasi kapur sirih dan lama perendaman yang berbeda berpengaruh nyata $(\alpha=5 \%)$ terhadap kadar air.

Tabel 2. Nilai Kadar Air Tepung Bonggol Pisang Kepok dengan Perlakuan Konsentrasi Kapur Sirih dan Lama Perendaman

\begin{tabular}{lc}
\hline \multicolumn{1}{c}{ Perlakuan } & Kadar Air (\%) \\
\hline Konsentrasi Kapur Sirih : & \\
F1 (Konsentrasi kapur sirih 5\%) & $6,7^{\mathrm{a}}$ \\
F2 (Konsentrasi kapur sirih 10\%) & $8,0^{\mathrm{b}}$ \\
F3 (Konsentrasi kapur sirih 15\%) & $8,0^{\mathrm{b}}$ \\
\hline Lama Perendaman : & \\
T1 (Lama perendaman 30 menit) & $6,6^{\mathrm{a}}$ \\
T2 (Lama perendaman 60 menit) & $7,9^{\mathrm{b}}$ \\
T3 (Lama perendaman 120 menit) & $8,2^{\mathrm{b}}$ \\
\hline
\end{tabular}

Keterangan: Angka rerata yang diikuti huruf yang sama menunjukkan tidak berbeda nyata berdasarkan Uji Duncan pada taraf $5 \%$.

Kadar air tepung bonggol pisang kepok dengan konsentrasi kapur sirih yang berbeda berkisar antara 6,7-8\%. Peningkatan kadar air seiring dengan semakin tingginya penambahan konsentrasi kapur sirih. Menurut Silvia (2015), fungsi ion $\mathrm{Ca}^{2+}$ pada kapur sirih adalah membentuk $\mathrm{Ca}^{-}$pekat, mekanisme ion $\mathrm{Ca}^{2+}$ membentuk ikatan menyilang dengan molekul pektin dan menghasilkan $\mathrm{Ca}^{-}$ pekat. Ca pekat ini menyebabkan kandungan air dalam bahan meningkat, sehingga kedudukan air dalam bahan akan bertambah. Lama perendaman yang berbeda berkisar antara 6,6-8,2\%. Peningkatan kadar air seiring dengan semakin lama perendaman dengan kapur sirih. Peningkatan kadar air ini disebabkan oleh kemampuan dari komponen penyusun bonggol pisang kepok dalam menyerap air salah satunya karbohidrat. Hal tersebut sama dengan pernyataan Carina (2012), bahwa semakin lamanya perendaman, proses dispersi air dalam protein semakin maksimal, sehingga kadar air semakin meningkat. Kadar air dalam bahan pangan sangat mempengaruhi kualitas dan daya simpan dari bahan pangan tersebut.

\section{Kadar Abu}

Berdasarkan hasil analisis ragam menunjukkan bahwa tidak terjadi interaksi antara konsentrasi kapur sirih dan lama perendaman, namun konsentrasi kapur sirih dan lama perendaman menunjukan berpengaruh sangat nyata $(\alpha=1 \%)$ terhadap kadar abu.

Kadar abu tepung bonggol pisang kepok dengan konsentrasi kapur sirih yang berbeda berkisar antara 7,4-8\%. Peningkatan kadar abu seiring dengan semakin 
tingginya penambahan konsentrasi kapur sirih. Kadar abu akibat lama perendaman yang berbeda berkisar antara 6,8-8,3\%. Peningkatan kadar abu seiring dengan semakin lama waktu perendaman. Kadar abu tertinggi yaitu lama perendaman 120 menit sebesar 8,3\% dan berbeda nyata dengan perlakuan F2 sebesar 7,7\% dan F3 sebesar 8,3\%. Pengukuran kadar abu penting dilakukan untuk mengetahui kandungan mineral dalam produk pangan. Semakin lama perendaman dalam larutan jenuh bahan pengeras, maka semakin tinggi kadar abu yang dihasilkan karena semakin lama direndam maka semakin banyak kalsium yang terserap kedalam jaringan bahan sehingga semakin tinggi kadar abunya (Prihatinningtyas, 2013).

Tabel 3. Nilai Kadar Abu Tepung Bonggol Pisang Kepok dengan Perlakuan Konsentrasi Kapur Sirih dan Lama Perendaman

\begin{tabular}{lc}
\hline \multicolumn{1}{c}{ Perlakuan } & Kadar Abu (\%) \\
\hline Konsentrasi Kapur Sirih : & $7,4^{\mathrm{a}}$ \\
F1 (Konsentrasi kapur sirih 5\%) & $7,4^{\mathrm{a}}$ \\
F2 (Konsentrasi kapur sirih 10\%) & $8,0^{\mathrm{b}}$ \\
F3 (Konsentrasi kapur sirih 15\%) & \\
\hline Lama Perendaman : & $6,8^{\mathrm{a}}$ \\
T1 (Lama perendaman 30 menit) & $7,7^{\mathrm{b}}$ \\
T2 (Lama perendaman 60 menit) & $8,3^{\mathrm{c}}$ \\
T3 (Lama perendaman 120 menit) &
\end{tabular}

Keterangan: Angka rerata yang diikuti huruf yang sama menunjukkan tidak berbeda nyata berdasarkan Uji Duncan pada taraf $5 \%$

\section{Kadar Lemak}

Berdasarkan hasil analisis ragam menunjukkan bahwa tidak terjadi interaksi antara konsentrasi kapur sirih dan lama perendaman, namun konsentrasi kapur sirih berpengaruh sangat nyata $(\alpha=1 \%)$ dan lama perendaman menunjukan berpengaruh nyata $(\alpha=5 \%)$ terhadap kadar lemak. Kadar lemak tepung bonggol pisang kepok dengan konsentrasi kapur sirih yang berbeda berkisar antara 3,6-5,1\%. Kadar lemak tertinggi pada perlakuan F1 yaitu 5,1\% dan berbeda nyata dengan perlakuan F2 sebesar 3,9\% dan F3 sebesar 3,6\%. Kadar lemak pada lama perendaman yang berbeda berkisar antara 3,5-4,8\%. Kadar lemak tertinggi pada perlakuan $\mathrm{T} 1$ yaitu 4,8\% dan berbeda nyata dengan perlakuan T2 sebesar 4,1\% dan T3 sebesar 3,5\%. 
Tabel 4. Nilai Kadar Lemak Tepung Bonggol Pisang Kepok dengan Perlakuan Konsentrasi Kapur Sirih dan Lama Perendaman

\begin{tabular}{lc}
\hline \multicolumn{1}{c}{ Perlakuan } & Kadar Lemak (\%) \\
\hline Konsentrasi Kapur Sirih : & \\
F1 (Konsentrasi kapur sirih 5\%) & $5,1^{\mathrm{b}}$ \\
F2 (Konsentrasi kapur sirih 10\%) & $3,7^{\mathrm{a}}$ \\
F3 (Konsentrasi kapur sirih 15\%) & $3,6^{\mathrm{a}}$ \\
\hline Lama Perendaman : & \\
T1 (Lama perendaman 30 menit) & $4,8^{\mathrm{b}}$ \\
T2 (Lama perendaman 60 menit) & $4,1^{\mathrm{ab}}$ \\
T3 (Lama perendaman 120 menit) & $3,5^{\mathrm{a}}$ \\
\hline
\end{tabular}

Keterangan: Angka rerata yang diikuti huruf yang sama menunjukkan tidak berbeda nyata berdasarkan Uji Duncan pada taraf $5 \%$.

Larutan kapur sirih mempengaruhi kecepatan reaksi hidrolisis sehingga semakin lama perendaman dengan kapur sirih maka kadar lemak semakin menurun. Hal ini sesuai dengan pernyataan Wira (2019), yang menyatakan dengan adanya enzim yang dibantu oleh air, lemak dapat terhidrolisis menjadi gliserol dan asam lemak. Reaksi ini dipercepat oleh asam dan basa (Potoh, 2019).

\section{Kadar Protein}

Berdasarkan hasil analisis ragam menunjukkan bahwa tidak terjadi interaksi antara konsentrasi kapur sirih dan lama perendaman, namun konsentrasi kapur sirih berpengaruh nyata $(\alpha=5 \%)$ dan lama perendaman tidak berpengaruh nyata terhadap kadar protein yang dihasilkan.

Tabel 5. Nilai Kadar Protein Tepung Bonggol Pisang Kepok dengan Perlakuan Konsentrasi Kapur Sirih

\begin{tabular}{cc}
\hline Perlakuan & Kadar Protein (\%) \\
\hline F1 (Konsentrasi kapur sirih 5\%) & $3,7^{\mathrm{b}}$ \\
F2 (Konsentrasi kapur sirih 10\%) & $2,9^{\mathrm{a}}$ \\
F3 (Konsentrasi kapur sirih 15\%) & $2,8^{\mathrm{a}}$ \\
\hline
\end{tabular}

Keterangan: Angka rerata yang diikuti huruf yang sama menunjukkan tidak berbeda nyata berdasarkan Uji Duncan pada taraf $5 \%$.

Kadar protein tepung bonggol pisang kepok dengan konsentrasi kapur sirih yang berbeda berkisar antara 2,8-3,7\%. Kadar protein tertinggi yaitu F1 sebesar 3,7\% dan berbeda nyata dengan perlakuan F2 sebesar 2,9\% dan F3 sebesar 2,8\%. Hal ini disebabkan karena kapur sirih dapat mengikat protein membentuk endapan. Semakin tinggi konsentrasi kapur sirih semakin banyak protein yang terikat dan membentuk endapan. Endapan terjadi karena kemampuan larutan kapur sirih untuk mencapai titik isoelektrik. Hal ini sesuai dengan pernyataan Junaini 
(2019), yang menyatakan endapan terjadi karena kemampuan setiap larutan untuk mencapai titik isoelektrik.

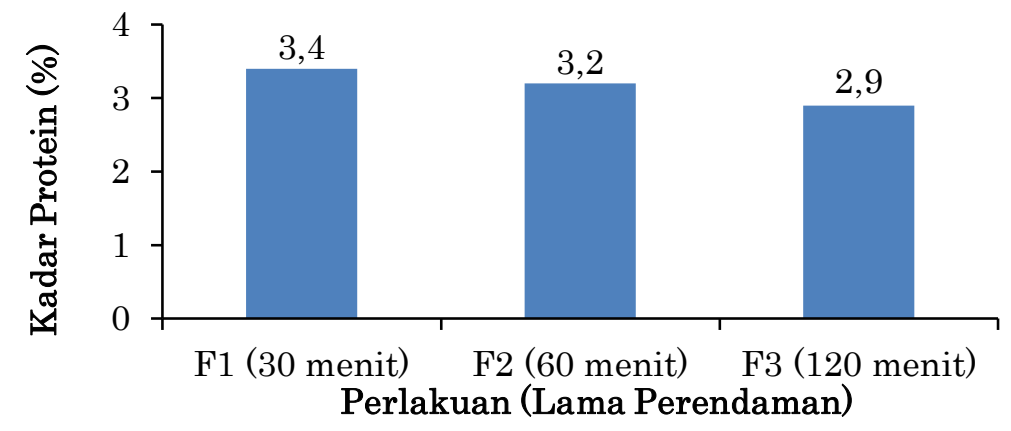

Gambar 2. Histogram Nilai Kadar Protein Tepung Bonggol Pisang Kepok dengan Lama Perendaman.

Kadar protein tepung bonggol pisang kepok dengan lama perendaman yang berbeda berkisar antara 2,9-3,4\%. Kadar protein perlakuan lama perendaman 30 menit sebesar 3,4\% serta perlakuan lama perendaman 60 menit sebesar $3,2 \%$ dan 120 menit sebesar 2,9\%. Hal ini disebabkan $\mathrm{Ca}(\mathrm{OH})_{2}$ menjadi ion $\mathrm{Ca}^{+2}$ dan $2 \mathrm{OH}^{-}$, yang mengikat koloid protein bernuatan (+) berikatan dengan $2 \mathrm{OH}^{-}$, sedangkan muatan (-) berikatan dengan $\mathrm{Ca}^{+2}$ dimana sebagian terlarut bersama air sehingga menurunkan kadar protein tepung (Prihatinningtyas, 2013).

\section{Total Karbohidrat}

Berdasarkan hasil analisis ragam menunjukkan bahwa tidak terjadi interaksi antara konsentrasi kapur sirih dan lama perendaman, namun konsentrasi kapur sirih dan lama perendaman menunjukan tidak berpengaruh terhadap total karbohidrat yang dihasilkan.

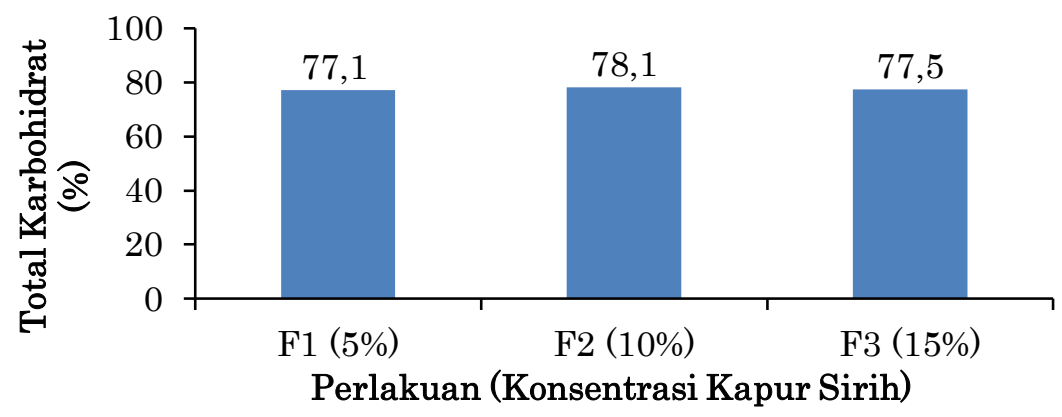

Gambar 3. Histogram Nilai Karbohidrat Tepung Bonggol Pisang Kepok dengan Perlakuan Konsentrasi Kapur Sirih.

Total karbohidrat tepung bonggol pisang kepok dengan konsentrasi yang berbeda berkisar antara 77,1-78,1\%. Total karbohidrat perlakuan F2 sebesar 78,1\% dan F1 sebesar 77,1\% dan F3 yaitu sebesar 77,5\%. Total karbohidrat dihitung secara by difference dipengaruhi oleh komponen nutrisi lain yaitu protein, lemak, air, dan 
abu, semakin tinggi komponen nutrisi lain maka total karbohidrat semakin rendah dan sebaliknya apabila komponen nutrisi lain semakin rendah maka total karbohidrat semakin tinggi (Aminah, 2018).

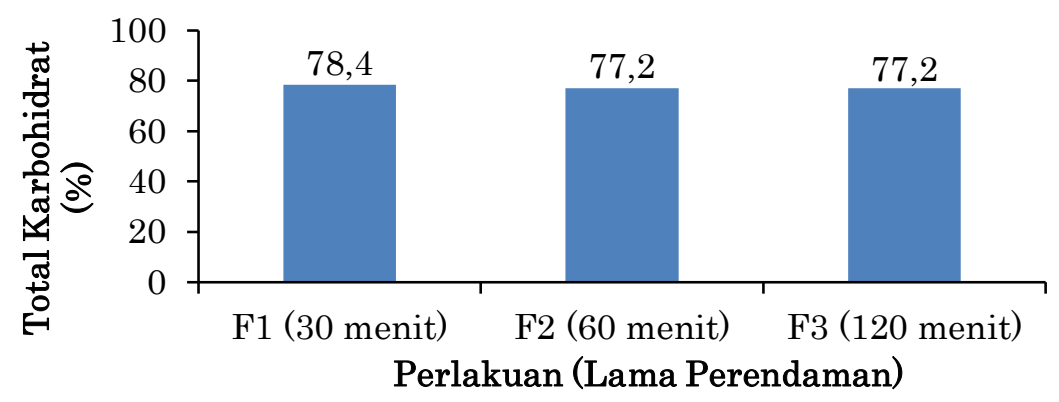

Gambar 4. Histogram Nilai Karbohidrat Tepung Bonggol Pisang Kepok dengan Perlakuan Lama Perendaman.

Total karbohidrat tepung bonggol pisang kepok dengan lama perendaman yang berbeda berkisar antara 77,2-78,4\%. Total karbohidrat perlakuan F1 sebesar 78,4\% dan perlakuan F2 dan F3 yaitu sebesar 77,2\%. Menurut Lestari (2017), menyatakan penurunan total karbohidrat disebabkan senyawa karbohidrat terlarut dalam larutan $\mathrm{Ca}(\mathrm{OH})_{2}$ karena dapat meningkatkan tekanan osmosis, sehingga senyawa- senyawa monosakarida dan disakarida lebih banyak terdifusi ke dalam $\mathrm{Ca}(\mathrm{OH})_{2}$.

\section{Organoleptik Kenampakan}

Berdasarkan hasil analisis ragam diketahui bahwa rasio tepung terigu dengan tepung bonggol pisang kepok berpengaruh sangat nyata terhadap kenampakan Cookies.

Tabel 6. Nilai Uji Organoleptik Cookies Atribut Kenampakan

\begin{tabular}{cc}
\hline Proporsi Cookies Tepung Terigu (\%) : Tepung Bonggol & $\begin{array}{c}\text { Skor } \\
\text { kenampakan }\end{array}$ \\
Pisang kepok (\%) & $7,6^{\mathrm{b}}$ \\
P0 (100:0) & $8,0^{\mathrm{b}}$ \\
P1 (85: 15) & $6,4^{\mathrm{a}}$ \\
P2 (70:30) & $5,4^{\mathrm{a}}$ \\
\hline P3 (65: 45)
\end{tabular}

Keterangan: 1. Amat sangat tidak menarik 2. Sangat tidak menarik 3. Tidak menarik 4. Agak tidak menarik 5. Netral 6. Agak menarik 7. Menarik8. Sangat menarik 9. Amat sangat menarik

Kenampakan cookies dengan substitusi tepung bonggol pisang kepok memiliki skor 5,4-8,0 yang berarti netral-sangat menarik. Tepung bonggol pisang kepok memiliki warna kecoklatan, sehingga cookies dengan substitusi tepung bonggol pisang kepok tertinggi menghasilkan warna kecoklatan. Wira (2019), bahwa masalah utama substitusi tepung bonggol pisang kepok adalah warna cookies 
yang dihasilkan agak kecoklatan jika penambahan tepung bonggol pisang lebih di atas $25 \%$.

\section{Organoleptik Aroma}

Berdasarkan hasil analisis ragam diketahui bahwa rasio tepung terigu dengan tepung bonggol pisang kepok berpengaruh sangat nyata terhadap aroma Cookies. Tabel 7. Nilai Uji Organoleptik Cookies Atribut Aroma

\begin{tabular}{cc}
\hline Proporsi Cookies Tepung Terigu (\%) : Tepung Bonggol & Skor Aroma \\
Pisang kepok (\%) & $7,4^{\mathrm{b}}$ \\
\hline P0 (100: 0) & $7,3^{\mathrm{b}}$ \\
P1 (85: 15) & $6,6^{\mathrm{a}}$ \\
P2 (70:30) & $6,2^{\mathrm{a}}$ \\
\hline P3 (65: 45)
\end{tabular}

Keterangan: 1. Amat sangat tidak suka 2. Sangat tidak suka 3. Tidak suka 4. Agak tidak suka 5. Netral 6. Agak suka 7. Suka 8. Sangat Suka 9. Amat sangat Suka

Aroma cookies dengan substitusi tepung bonggol pisang kepok memiliki skor 6,27,4 yang berarti agak suka-suka. Cookies substitusi tepung bonggol pisang kepok sebesar $30 \%$ dan $45 \%$ memiliki hasil yang berbeda nyata dengan cookies $100 \%$ tepung terigu protein rendah dan subtitusi tepung bonggol pisang kepok sebesar 15\%. Tepung bonggol pisang memiliki aroma yang khas bonggol pisang yang belum banyak orang ketahui. Aroma dari tepung terigu yang tawar/netral dan sudah banyak dikenali sehingga formula aroma cookies 100\% tepung terigu lebih dipilih karena aromanya lebih bisa diterima dan tidak memiliki aroma khas. Menurut Wira (2019) bonggol pisang kepok memiliki aroma khas yang keluar dari bonggol yang masih basah ataupun sudah menjadi tepung.

\section{Organoleptik Rasa}

Berdasarkan hasil analisis ragam diketahui bahwa rasio tepung terigu dengan tepung bonggol pisang kepok berpengaruh sangat nyata terhadap rasa cookies.

Tabel 8. Nilai Uji Organoleptik Cookies Atribut Rasa

\begin{tabular}{cc}
\hline Proporsi Cookies Tepung Terigu (\%) : Tepung Bonggol & Skor Rasa \\
Pisang kepok (\%) & $7,5^{\mathrm{b}}$ \\
\hline P0 (100: 0) & $7,8^{\mathrm{b}}$ \\
P1 (85: 15) & $6,6^{\mathrm{a}}$ \\
P2 (70:30) & $6,4^{\mathrm{a}}$ \\
\hline P3 (65:45)
\end{tabular}

Keterangan: 1. Amat sangat tidak enak 2. Sangat tidak enak 3. Tidak enak 4. Agak tidak enak 5. Netral 6. Agak enak 7. Enak 8.Sangat enak 9. Amat sangat enak 
Rasa cookies yang dihasilkan memiliki skor 6,4-7,8 yang berarti agak enak-sangat enak. Cookies 100\% tepung terigu protein rendah, tidak berbeda nyata dengan cookies substitusi tepung bonggol pisang kepok 15\%. Cookies dengan subtitusi tepung bonggol pisang kepok sebesar 30\% dan 45\% hasilnya berbeda nyata dengan cookies $100 \%$ tepung terigu protein rendah dan substitusi tepung bonggol pisang kepok 15\%. Menurut Aminah (2018), menyatakan tepung bonggol pisang kepok sebagai bahan baku pengganti terigu dalam proses pembuatan cookies, mempunyai rasa sepat atau ketir dikarenakan bonggol pisang kepok terdapat getah yang mengandung saponin dan zat tanin dimana mempengaruhi rasa pada tepung bonggol pisang kepok yang dihasilkan untuk diolah menjadi cookies (Hidayah, 2021).

\section{Organoleptik Tekstur}

Berdasarkan hasil analisis ragam diketahui bahwa rasio tepung terigu dengan tepung bonggol pisang kepok berpengaruh sangat nyata terhadap rasa cookies.

Tabel 9. Nilai Uji Organoleptik Tekstur Atribut Tekstur

\begin{tabular}{cc}
\hline Proporsi Cookies Tepung Terigu (\%) : Tepung Bonggol & Skor Tekstur \\
Pisang kepok (\%) & $7,9^{\mathrm{b}}$ \\
P0 (100:0) & $7,9^{\mathrm{b}}$ \\
P1 (85: 15) & $6,4^{\mathrm{a}}$ \\
P2 (70:30) & $5,9^{\mathrm{a}}$ \\
\hline P3 (65:45)
\end{tabular}

Keterangan: 1. Amat sangat tidak renyah 2. Sangat tidak renyah 3. Tidak renyah 4. Agak tidak renyah 5. Netral 6. Agak renyah 7. Renyah 8. Sangat renyah 9. Amat sangat renyah

Tekstur cookies yang dihasilkan memiliki skor 5,9-7,9 yang berarti agak renyahsangat renyah. Cookies $100 \%$ tepung terigu protein rendah berbeda nyata dengan cookies substitusi tepung bonggol pisang kepok 30\% dan 45\%. Cookies yang paling disukai oleh panelis menurut atribut tekstur adalah cookies 100\% tepung terigu protein rendah dan cookies substitusi tepung bonggol pisang kepok 15\%. Cookies substitusi tepung bonggol pisang kepok 30\% dan 45\%, panelis kurang menyukai. Tepung bonggol pisang mempunyai kandungan serat yang tinggi sehingga, semakin banyak proporsi tepung bonggol pisan tekstur menjadi keras. Menurut Titin (2018), bonggol pisang mempunyai kandungan serat kasar 20\%.

\section{KESIMPULAN}

Perlakuan konsentrasi dan lama perendaman kapur sirih tidak memiliki interaksi terhadap kualitas tepung bonggol pisang kepok. Konsentrasi larutan kapur sirih berpengaruh nyata terhadap kadar air, kadar abu, kadar lemak dan protein pada kualitas tepung bonggol pisang kepok. Lama perendaman larutan kapur sirih berpengaruh nyata terhadap tingkat kecerahan (L), kadar air, kadar 
abu dan kadar lemak pada kualitas tepung bonggol pisang kepok. Cookies terbaik adalah formulasi tepung terigu dan bonggol pisang kepok (85\%:15\%) dengan perolehan skor uji organoleptik kenampakan sebesar 8 (sangat menarik) dan perolehan skor uji organoleptik rasa sebesar 7,8 (sangat enak).

\section{DAFTAR PUSTAKA}

[AOAC] Association of Official Analytical and Chemistry. 2005. Official Methode of Analysis. 18 ${ }^{\text {th }}$ ed. Marylan: Association of Official Analytical Chemist inc.

Aminah. A., \& Nurul A., 2018. Pemanfaatan Kombinsai Kulit Kacang Dengan Bonggol Pisang dan Biji Nangka Untuk Pembuatan Platik Biodegradable Dengan Penambahan Gliserol. Jurnal Penelitian Biologi, 4(1), pp. 11-19. DOI: https://doi.org/10.23917/bioeksperimen.v4i1.5924

Asnani, A. \& Abdul, R., 2019. Karakteristik Fisik, Kimia dan Organoleptik Mie Kering Pada Berbagai Rasio Tepung Bonggol Pisang Kepok. Jurnal Teknologi Industri Pertanian, $13 \quad$ (1), pp.82-90. DOI: https://doi.org/10.21107/agrointek.v13i1.4918

Carina, W., 2012. Pengembangan Belimbing Wuluh Sebagai Manisan Kering dengan Kajian Konsentrasi Perendaman Air Kapur $\left(\mathrm{Ca}(\mathrm{OH})_{2}\right)$ dan Lama Waktu Pengeringan. Jurnal Industri 1, 4(2), pp. 195-203

Hamidah, S. \& Sutriyati. 2009. Patiseri. Universitas Negeri Yogyakarta. Yogyakarta.

Harahap, \& Asni D., 2017. Pengaruh Substitusi Penambahan Tepung Bonggol Pisang (Musa paradisiaca) Terhadap Daya Terima Bolu Kukus. Skripsi. Politeknik Kesehatan Kemenkes Medan. Lubuk Pakam.

Hidayah. 2021. Inovasi Pembuatan Pie Susu Substitusi Tepung Bonggol Pisang Kepok (Musa acuminate L.). Jurnal teknologi busana dan boga, 9 (2), pp. 141147. DOI: https://doi.org/10.15294/teknobuga.v9i2.27964

Jagat, A. N. \& Yoyok, B. P., 2017. Pengkayaan Serat pada Pembuatan Biskuit dengan Substitusi Tepung Ubi Jalar Kuning (Ipomea batatas L.). Jurnal Aplikasi Teknologi Pangan, $6 \quad$ (2), pp.49-57. DOI: http://dx.doi.org/10.17728/jatp.190

Junaini, Elvinawati, \& Sumpono. 2019. Pengaruh Kadar Aspergillus niger Terhadap Produksi Bioetanol Dari Bonggol Pisang Kepok (Musa paradisiaca L). Jurnal Pendidikan Dan Ilmu Kimia, 3 (2), pp. 176-184. DOI: https://doi.org/10.33369/atp.v3i2.10496

Lensun, C. \& Erny, J.N., 2013. Pemanfaatan Sagu Baruk (Arenga microcarpa) dengan Ubi Jalar Ungu (Ipomoea batatas) Dalam Pembuatan Mie Basah. Jurnal Ilmu dan Teknologi Pangan, 3(6), pp. 1-8. DOI: https://doi.org/10.35791/cocos.v3i6.3340

Lestari, E. 2017. Karakterisasi Tepung Kacang Hijau dan Optimasi Penambahan Tepung Kacang Hijau Sebagai Pengganti Tepung Terigu Dalam Pembuatan Kue Bingka. Jurnal Teknologi Agro-Industri, 4 (1), pp. 20-34, DOI: https://doi.org/10.34128/jtai.v4i1.45 
Nurainy, F. 2013. Pengaruh Konsentrasi CaCl2 dan Lama Perendaman Terhadap Sifat Organoleptik Keripik Pisang Muli (Musa paradisiaca L.) Dengan Penggorengan Vakum (Vacuum Frying). Jurnal Teknologi dan Industri Hasil Pertanian, $18 \quad$ (1), pp.78-90. DOI: http://dx.doi.org/10.23960/jtihp.v18i1.78\%20-\%2090

Potoh \& J. Mandey. 2019. Pengaruh Pemanfaatan Bonggol Pisang Sepatu (Musa paradisiaca L) Dalam Ransum Terhadap Persentase Karkas dan Lemak Abdominal Ayam Broiler. Jurnal animal science, 39 (2), pp 1-20. DOI: https://doi.org/10.35792/zot.39.2.2019.25757

Prihatinningtyas, E. \& Jatnika, A., 2013. Aplikasi Koagulan Alami Dari Tepung Jagung Dalam Pengolahan Air Bersih. Jurnal Ilmiah Sains dan Teknologi, 2 (2), pp.71-158. DOI: https://doi.org/10.22146/teknosains.5999

Ridhayanti. 2017. Pengaruh Persentase dan Lama Perendaman Dalam Larutan Kapur Sirih $\left(\mathrm{Ca}(\mathrm{OH})_{2}\right)$ terhadap Kualitas Keripik Pepaya (Carica papaya L.) Dengan Vacuum Frying. Jurnal Pendidikan Teknologi Pertanian, 3(1), pp. S221-S233. DOI: https://doi.org/10.26858/jptp.v3i0.5721

Silvia, W. \& Farida, F., 2015. Pengaruh Berbagai Komposisi Limbah Pertanian Terhadap Kadar Air, Abu, dan Serat Kasar Pada Wafer. Jurnal Ilmiah Peternakan Terpadu, 3(3), pp.104-109. DOI: http://dx.doi.org/10.23960/jipt.v3i3.p\%25p

Sudarmadji, S., Suhardi, \& Haryono, B. 2007. Analisis Bahan Makanan dan Pertanian. Yogyakarta: Liberty.

Suhami, S., 2016. Pendugaan Umur Simpan Tepung Biji Durian (Durio zibethinus) Dengan Menggunakan Persamaan Arrhenius. Jurnal Rona Teknik Pertanian, 9(1), pp.74-88. DOI: https://doi.org/10.17969/rtp.v9i1.4409

Titin, A. \& Isnin, A., 2018. Karakteristik Fisik, Kandungan Gizi Tepung Kulit Pisang dan Perbandingannya Syarat Mutu Tepung Terigu. Jurnal Riset Sains dan Teknologi, 2 (2), pp. 45-50. DOI: 10.30595/jrst.v2i2.3094

Wira, L. \& Risa, P., 2019. Pemanfaatan Tepung Bonggol Pisang Kepok (Musa acuminata Balbisiana) Menjadi Choco Cookies. Jurnal Bosaparis Pendidikan Kesejahteraan Keluarga, 10(3), pp.195-204. DOI: $\underline{\text { http://dx.doi.org/10.23887/jjpkk.v10i3.22158 }}$ 